\title{
USING ARDUINO BOARD FOR AUTOMATIC PULSE IRRIGATION SYSTEM
}

\author{
A. M. Okasha ${ }^{1}$
}

\section{ABSTRACT}

Nowadays the scarcity of water is a source of great concern for agriculture and using technology to control irrigation systems has become an essential requirement. A laboratory and outdoor work were carried out at Agricultural Engineering Department, Faculty of Agriculture, Kaferelsheikh University during summer 2016. The aim of this work is designing a system which is capable of on/off the water pump for pulse irrigation system in time. Arduino board and other hardware is programmed at 20 min.on/20min.off (possible to change) with the Arduino software. The proposed prototype can help in reducing hard work of pulse irrigation system due to on/off valves manually, cost and save time. The uses of moisture sensor and solenoid valve make a smart irrigation system. Arduino based automatic watering system has been designed and tested successfully by part of second.

\section{1-INTRODUCTION}

pplication of new technologies to control of irrigation water
requirements has become very important. Addition to
generation and implementation of automatic irrigation schedules are receiving increased attention to adjust the amount of water and in suitable time and saving of human efforts. Mostaghimi and Mitchell (1983) indicated that on/off trickling wets a greater volume of soil with the same amount of applied water. Thus, reduction in the downward movement of soil moisture under pulsed applications would cause less deep drainage below the root zone. Zin El-Abedin (2006) showed that pulse drip irrigation is a recent concept where small frequent irrigation applications are applied to saturate the soil and meet the plant water requirements. Skaggs et al. (2010) used a numerical simulations and field trials to investigate the effects of application rate, pulsed water

\footnotetext{
${ }^{1}$ Asst. Prof. Agric. Eng. Dept., Faculty of Agric, Kafrelsheikh University, Egypt.
} 
application, and antecedent water content on the spreading of water from drip emitters. Simulation results showed that pulsing and lower application rates produced minor increases in horizontal spreading at the end of water application. The small increases were primarily due to longer irrigation times, however, and not to flow phenomena associated with pulsing or low application rates. Zapata et al. (2013) indicated that automatic irrigation treatments resulted in similar maize yield but using less water than manual irrigation. Eid et al. (2013) found that pulse drip irrigation and mulching systems tended to increase and improving the yield of soybean. Applying the irrigation requirements on 8 pulses/day with using black plastic mulch (BPM) was the best conditions. Thalheimer (2013) developed a low cost system for measuring soil water potential and data logging on the basis of an Arduino microcontroller board, electronic pressure transducers and water-filled tensiometers. Angal (2013) presented a home automation system which is based on Raspberry pi, Arduino microcontrollers, and zigbee and relay boards to water plants. Raspberry pi acts as the control block in the automatic irrigation system to control the flow of motor. The commands from the Arduino are processed at raspberry pi. Zigbee module is used for communication between the Raspberry pi and Arduino. Devika et al. (2014) used watering sprinkler system by Arduino board, which consists of ATmega328 Microcontroller to water the plants located in the pots. Latha and Devabhaktuni (2014) showed that Arduino is a small microcontroller board with a USB plug to connect to the computer and a number of connection sockets that can be wired up to external electronics, such as motors, relays, light sensors, laser diodes, loudspeakers, microphones, etc. They can either be powered through the USB connection from the computer or from a 9V battery. They can be controlled from the computer or programmed by the computer and then disconnected and allowed to work independently. Rhman et al. (2014) represented a system consists of the main unit that by an Arduino Uno board which include an ATmega328 microcontroller, different sensors as moisture sensors, temperature sensors, humidity sensors, XBee modules and solenoid valve for smart irrigation. Nikolidakis et al. (2015) proposed automated irrigation management system comprises of 
two subsystems. The first subsystem concerns the Wireless Sensor Network (WSN) which collects the data from the cultivated fields. The second subsystem involves the decision making system. Manoj and Udupa (2015) reported that Arduino board and soil moisture sensor based irrigation system proves to be a real time response control system which monitors and wheel all the activities of irrigation system. Singh et al. (2015) mentioned that soil sensor can be used to detect the moisture of soil or judge if there is water around the sensor. Darshna et al. (2015) tested the smart irrigation system on a garden plant. The plant's water requirement was $600-800 \mathrm{~mm}$ a day and temperature requirement of the soil range from $50^{\circ} \mathrm{C}-100^{\circ} \mathrm{C}$. In the Arduino code, the moisture and temperature range were set as 300-700 and 450-800 respectively (which delineates the corresponding resistance value in digital format). Moreover this system proves to be cost effective and proficient in conserving water and reducing its wastage. Nagarajapandian et al. (2015) reported the benefit of employing these techniques is to decrease human interference and still make certain appropriate irrigation. This automated irrigation project brings into play an Arduino board ATmega328 micro-controller, is programmed to collect the input signal of changeable dampness circumstances of the earth via dampness detecting system. Agrawal and Singhal (2015) proposed a design for home automation drip system using ready-to-use, cost effective and energy efficient devices including raspberry pi, arduino microcontrollers, xbee modules and relay boards. Daniel et al. (2015) automated the process of irrigation on the farmland by monitoring the soil water level of the soil relative to the plant being cultivated and the adaptively sprinkling water to simulate the effect of rainfall. Central to this design is an Arduino Uno microcontroller which monitors the farm condition and controls the distribution of water on the farm. Mahesh et al. (2015) reported that in the irrigation area automatic system, high- performance embedded micro-controller and low-power technology is used to design the water wireless sensor network. Parameswaran and Sivaprasath (2016) said that arduino is an open-source computer hardware and software company, project and user community. It also designs and manufactures based kits for building digital devices and interactive 
objects that can sense and control objects with many devices. Kumar and Maru (2016) used Arduino board, which consists of ATmega328 Microcontroller. It is programmed in such a way that it will sense the moisture level of the plants and supply the water if required. This type of system is often used for general plant care, as part of caring for small and large gardens. Ellakkia et al. (2016) showed that measuring soil moisture is important for agricultural applications to help farmers manage their irrigation systems more efficiently. Knowing the exact soil moisture conditions on their fields, not only are farmers able to generally use less water to grow a crop, they are also able to increase yields and the quality of the crop by improved management of soil moisture during critical plant growth stages. Okasha et al. (2016) achieved the highest uniformity parameters, productivity and irrigation water use efficiency of soybean using pulsed drip irrigation in clay soil. Application of pulse or surge irrigation technique need to open and close water requirements, thus a great manpower or efforts to on and off valves manually in time. This problem was found during carrying out our investigation in summer of 2015. Therefore, the aim of the implementation was designing a prototype which is capable of on/off the water pump for pulse irrigation system and application water using arduino board and other hardware in time.

\section{HARDWARE DESCRIPTION}

The components of this system are arduino board, soil moisture sensor, relay, transistor, diode, bread board, solenoid valve, adaptor, water pump, Liquid Crystal Display (LCD), resistance and conductors are represented as flowing (Figure 1):-

\section{1-Arduino:}

It consider brain of the system. Microcontroller board based on the ATmega328. It has 14 digital input/output pins (of which 6 can be used as PWM outputs), 6 analog inputs, a $16 \mathrm{MHz}$ ceramic resonator, a USB connection, a power jack, an In Circuit Serial Programming (ICSP) header that a method for programming microcontrollers, and a reset button. It contains everything needed to support the microcontroller as shown in Figure 2. 


\section{2-Solenoid Valve:}

In this system a solenoid valve was used to be the actuator for controlling the water flow to start or stop the irrigation process according to the control signals that received from the microcontroller. Solenoid specifications are AC $24 \mathrm{~V}, 125 \mathrm{~mA}, 1.7 \mathrm{~W}$.

\section{3-Liquid Crystal Display (LCD):-}

The LCD has dimension of $80.8 \times 36.0 \times 12.5 \mathrm{~mm}$, format character-line of $16 \times 2$ and logic supply of 5VDC. It is the base station used for monitoring the state of nodes (on or off), and moisture content in the soil.

\section{4-Moisture Sensor:-}

The moisture sensor uses the two probes to pass current through the soil and then it reads that resistance to get the moisture level. Two wires placed in the soil pot form a variable resistor, whose resistance varies depending on soil moisture. This variable resistor was connected in a voltage divider configuration, and Arduino collects a voltage proportional to resistance between the two wires.

\section{5-Motor/Water Pump:-}

Maximum discharge $40 \mathrm{l} / \mathrm{min}$., elevation head $33 \mathrm{~m}$, suction head $8 \mathrm{~m}$ and AC $220 \mathrm{~V}-2.7 \mathrm{~A}$.It can be electronically controlled by interfacing it to a microcontroller. It can be triggered on/off by sending signals as required.

\section{6-Relay:-}

A relay is an electrically operated switch $(5 \mathrm{~V})$. Relays are used where it is necessary to control a circuit by a low power signal (with complete electrical isolation between control and controlled circuits), or where several circuits must be controlled by one signal.

\section{7-Transistor:}

Transistor is semiconductors used to amplify an electrical signal or switch an electrical signal on and off.

\section{8-Diode:}

Diode allows electricity to flow in one direction. When turn the power off to water pump, you get a negative spike of voltage that can damage the Arduino or the transistor. The diode protects against this, by shorting out any such reverse current from the motor/water pump. 


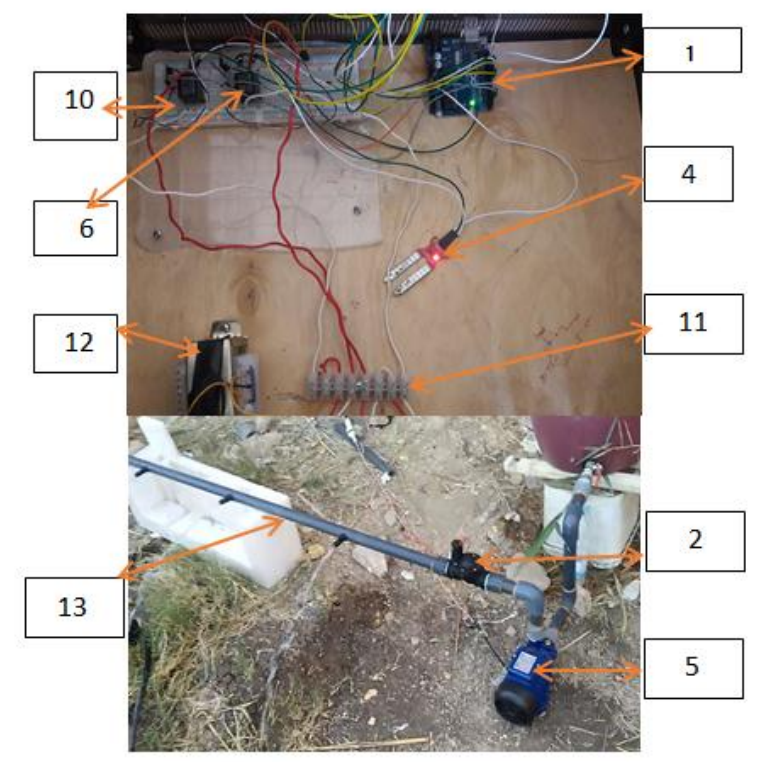

Figure 1: Main hardware of experimental prototype

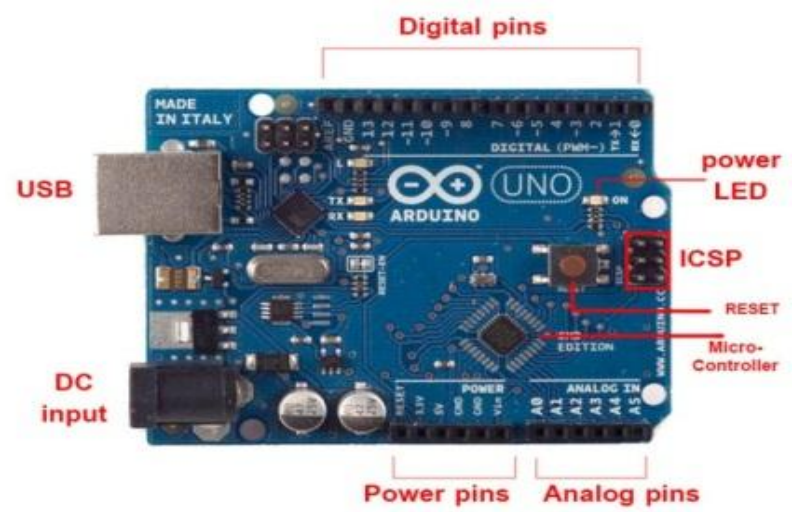

Figure2. Components of arduino board

\section{0- Breadboard:}

A breadboard also known as protoboard is a type of solderless electronic circuit building. You can build an electronic circuit on a breadboard without any soldering.

\section{1-Connecto Series (Rosetta) and electric wires:}

Rosetta used to connection of electric wire series.

\section{2- Adaptor:}

It considers that power transformer, the input voltage AC220V to output voltage $\mathrm{AC} 12 \mathrm{~V} \times 2$. 


\section{3-Pipes, Connectors:}

Pipe had diameter of $25.4 \mathrm{~mm}$, it is used to transmit water from tank to irrigation line.

\section{METHODOLOGY}

There are two functional hardware in this work. The motor/water pump and the moisture sensor. The arduino board was programmed using the Arduino IDE software. The function of the moisture sensor was to sense the level of moisture in the soil and calibrated by measurement of the resistance of the soil using gypsum blocks method. The output from analog pin was measured when the two probes were in the air (maximum resistance, moisture content equal zero\%) and inside a glass of water (minimum resistance, moisture content equal 100\%).

\subsection{Assembly}

Coding is to be composed using Arduino 1.6.10 software. USB cable connects the Arduino board to the laptop. LCD is connected to digital output of the Arduino board 8, 9, 10, 11, 12 and 13 to display instantaneous status of the system. Connect the soil moisture sensor to the arduino board analogue inputs A0. Solenoid valves and a Motor/PUMP were connected to digital output pins 2, and 3 respectively to the Arduino board with the help of relay as shown in Figure 3.

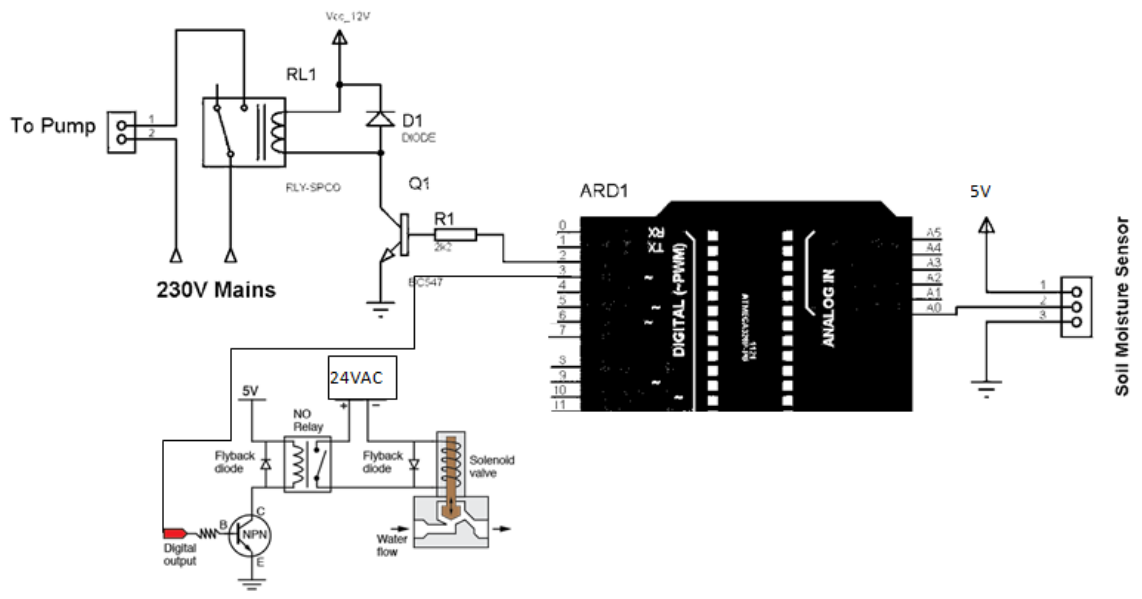

Figure 3. Electric circle of experimental system

\subsection{Software Description}

The microcontroller on the arduino Uno board the can be programmed with the Arduino software as shown in Figure 4. Select "Arduino Uno from the Tools > Board menu (based on Processing) as following steps 
1- When put a sensor in soil, Analog Soil Moisture on LCD

2- At sensor value was less than 300 , dry soil on LCD, signal (5V) to open motor/pump, then wait $900 \mathrm{~ms}$ and signal $(5 \mathrm{~V})$ to open solonid valve.

3- Afer $20 \mathrm{~min}$, signal (0V) to close motor/pump, then wait $900 \mathrm{~ms}$ and signal $(0 \mathrm{~V})$ to close solonid valve.

4- Reapat the pervious prossing until sensor moisture content value is greater than 300 .

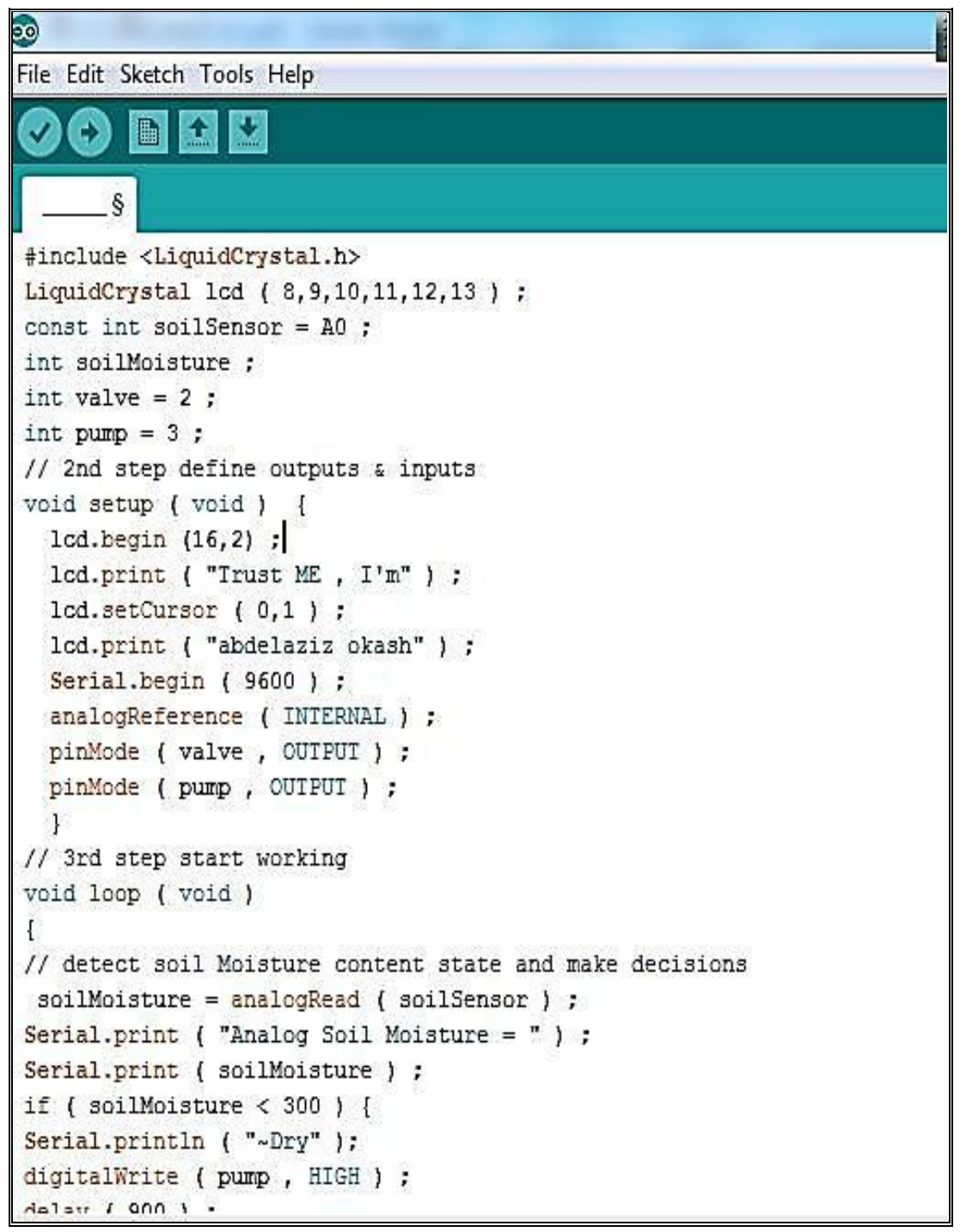

Figure. 4: Arduino software 


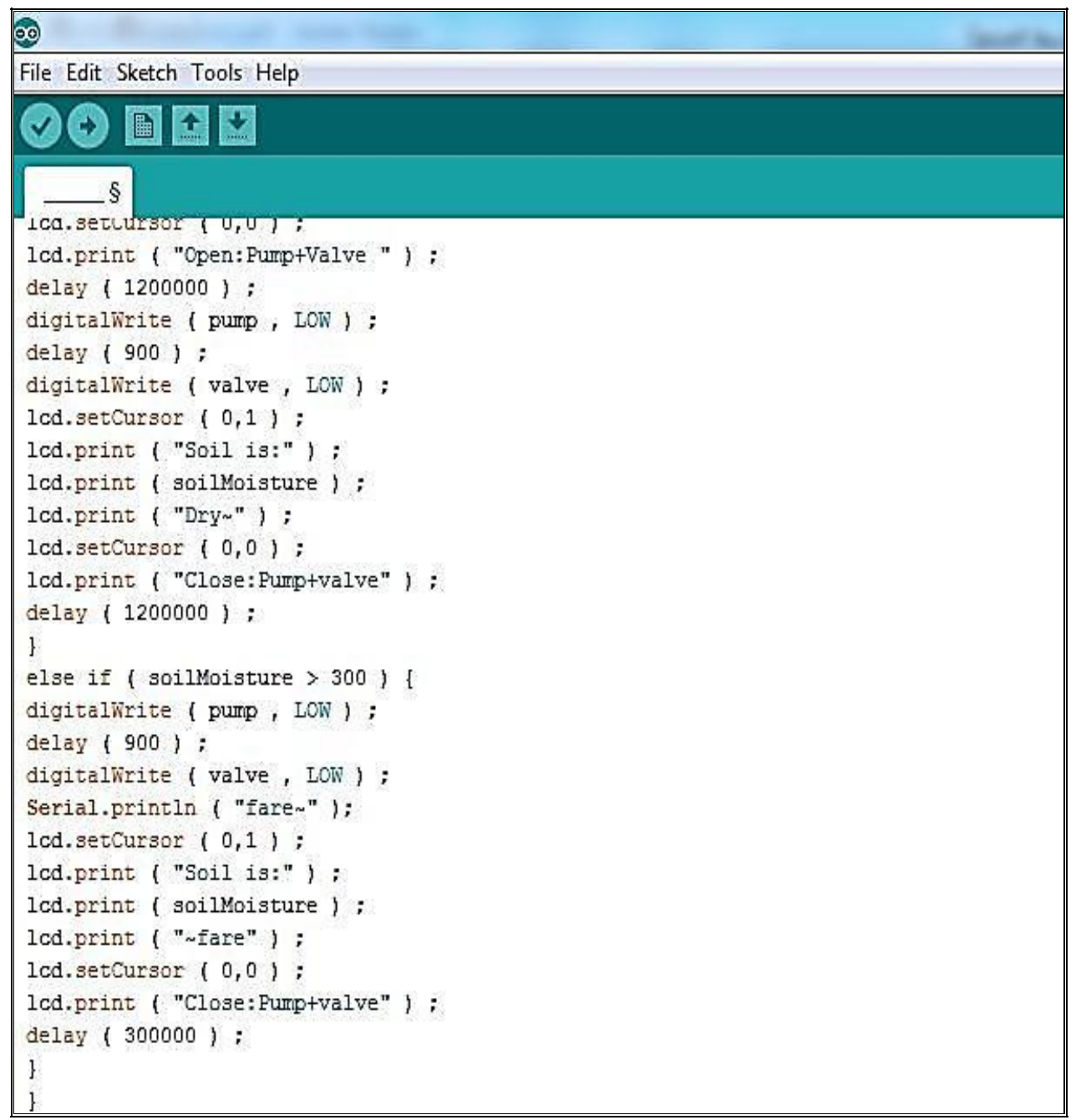

Cont. Figure 4. Arduino software

\subsection{Working Principles}

Using arduino board for pulsed automatic by open solenoid valve according to interval of irrigation and soil moisture content. Assume that the soil reach to moisture content after $20 \mathrm{~min}$. on/off and repeat three times for three lateral lines (water requirement). Calibration of soil moisture content at field capacity was (40\% wet basis) to correspond 300 on LCD (which delineates the corresponding resistance value in digital format). The relationship between moisture content and actual soil resistance as shown in following equation: 
$\mathrm{M}=9079.7 \mathrm{R}^{-1.063} \ldots \ldots \ldots \mathrm{r}^{2}=0.88$

Where:-

$$
\begin{aligned}
& \mathrm{M}=\text { moisture content, } \% \\
& \mathrm{R}=\text { Actual soil resistance, } \Omega
\end{aligned}
$$

\section{RESULTS AND DISCUSSION}

The proposed system was applied on outdoor field. The main advantage of this system achieved in operating pulse irrigation system became important to manage irrigation systems more efficiently based on soil moisture content. Using automatic controlling of water pump provides minimization of the time and less water in irrigation operation. The system provides with several benefits and can be operated with less manpower and cost saving as shown in Table 1. The system supplies water only when moisture content in the soil goes below the reference. Most of these results agreed with (Latha and devabhaktuni 2014).the system is efficient and compatible to changing of parameters according to water requirements.

Table 1 : Cost of the system components according to price of 2016

\begin{tabular}{|c|l|c|}
\hline No. & Component & Price, E.L \\
\hline 1 & Arduino Board & 110 \\
\hline 2 & Solenoid Valve & 200 \\
\hline 3 & LCD & 35 \\
\hline 6 & Water Tank & 50 \\
\hline 7 & Relay 5V & 10 \\
\hline 8 & Water/Motor Pump & 250 \\
\hline 9 & Bread Board & 23 \\
\hline 10 & Adaptor 24V & 35 \\
\hline 11 & $\begin{array}{l}\text { Transistor, Diode Resistance } \\
\text {..etc. }\end{array}$ & 30 \\
\hline Total & & $743^{*}$ \\
\hline
\end{tabular}

$* 1 \$=8.88 \mathrm{LE}$ 


\section{CONCLUSIONS}

> Automatic irrigation can be used to reduce water use, installed has no maintenance cost and is easy to use.

$>$ This proposal prototype greatly reduces the manpower, saves time and operates efficiently without human interference.

$>$ Contributes an efficient and fairly cheap automation irrigation system.

\section{REFERANCES}

Agrawal, N. and S. Singhal (2015). Smart drip irrigation system using raspberry pi and arduino. In Computing, Communication \& Automation (ICCCA), International Conference. IEEE.928-932.

Angal, S. (2013). Raspberry pi and Arduino Based Automated Irrigation System. International Journal of Science and Research (IJSR). 5(7):1145-1148

Daniel, A. T.; E. O. Ogunti and O. Daniela (2015). Development of a Smart Irrigation System. International Journal of Science and Engineering Investigations. 4(45): 27-31.

Darshna S.; T. Sangavi ; S. Mohan; A. Soundharya and S. Desikan (2015). Smart Irrigation System. Journal of Electronics and Communication Engineering. 10(3): 32-36

Devika, S. V.; S. Khamuruddeen; S. Khamurunnisa; J. Thota and K. Shaik (2014). Arduino Based Automatic Plant Watering System. International Journal of Advanced Research in Computer Science and Software Engineering, 4(10). pp. 449-456

Eid, A. R.; B. A. Bakry and M. H. Taha (2013). Effect of pulse drip irrigation and mulching systems on yield, quality traits and irrigation water use efficiency of soybean under sandy soil conditions. Agricultural Sciences. 4(5): 249-261. 
Ellakkia V.; G. P. Sheebha and P. Mahalakshmi (2016) Automated Embedded Technology for Smart Irrigation Using Arduino Controller. International Journal of Scientific Engineering and Applied Science (IJSEAS) 2(3):300-305.

Kumar, V. and U. Maru (2016). Automated Plants Watering System Using Arduino UNO Board. ETEMSD2016044.

Latha, D. P. and S. Devabhaktuni (2014). Soil Moisture and Temperature sensor based intelligent irrigation water pump controlling system Arduino. American Journal of Sustainable Cities and Society, 3(1), $2319-7277$.

Mahesh, V.; D. S. Rao and S. Subbanna (2015). Automated Irrigation System using a Wireless Sensor Network and GPRS Module. IJITECH, Vol.03,Issue.07, 1154-1160.

Manoj, H. G. and N. G. S. Udupa (2015). Application of Soil Moisture Sensor in Mixed Farming. International Research Journal of Engineering and Technology (IRJET). 2(4): 311-314.

Mostaghimi, S. and J. K. Mitchell (1983). Pulsed trickling effects on soil moisture distribution. American water resources association. 19(4):605-612.

Nagarajapandian, M.; U. R. Prasanth; G. S. Kumar and T. S. Selvan (2015). Automatic irrigation system on sensing soil moisture content. International Journal of Jnnovative Research in Electrical, Electronics, Instrumentation and Control Engineering. 3(1): 96-98.

Nikolidakis, S. A.; D.Kandris; D. D. Vergados and C. Douligeris (2015). Energy efficient automated control of irrigation in agriculture by using wireless sensor networks. Computers and Electronics in Agriculture, 113: 154-163. 
Okasha, A. M.; W.F. ELMetwally and T. M. Attaffy. (2016). Effect of Different Types of Irrigation System on Soybean Production under Clayey Soil Conditions. Misr J. Ag. Eng., 33 (1): 43-62.

Parameswaran, G. and K. Sivaprasath (2016). Arduino Based Smart Drip Irrigation System Using Internet of Things. International Journal of Engineering Science, 5518.

Rhman, Z. A.; R. S. Ali, and B. H Jasim (2014). Wirelessly Controlled Irrigation System. Iraq J. Electrical and Electronic Engineering. 10(2):89-99.

Singh, S.; S. Upreti; P. Sarkar and Y. Jain (2015). Arduino Based Automated Watering System. IJIRT, 2(6): 419420.

Skaggs, T. H.; T. J. Trout and Y. Rothfuss (2010). Drip irrigation water distribution patterns: effects of emitter rate, pulsing, and antecedent water. Soil Science Society of America Journal. 74(6): 1886-1896.

Thalheimer, M. (2013). A low-cost electronic tensiometer system for continuous monitoring of soil water potential. Journal of Agricultural Engineering, 44(3), 16.

Zapata, N.; R. Salvador; J. Cavero; S. Lecina; C.López; N. Mantero, and E.Playán (2013). Field test of an automatic controller for solid-set sprinkler irrigation. Irrigation Science, 31(5): 1237-1249.

Zin El-Abedin, T. Z. (2006). Effect of pulse drip irrigation on soil moisture distribution and maize production in clay soil. The 14th. Annual Conference of the Misr Society of Ag. Eng., 22 Nov: 10581076. 


\section{الملخص العربي \\ استخدام لوحة الاردوينو للتحكم الاوتوماتيكي في نظام الري النبضي \\ *د. عبدالعزيز محمد عكاشة}

اصبح الاهتمام بتوفير المياه للقطاع الزراعي واستخدام التكنولوجيا الحديثة للتحكم في أنظمة الري المختلفة امرا جوهريا، وخاصةً مع ندرة المياه. لذا تم تنفيذ عمل معملي واخر الزي خارجي بقسم الهندسة الزر اعية ـ كلية الزر اعة جامعة كفر الثيخ لتصميم نظام يستطيع التحكم في فتح

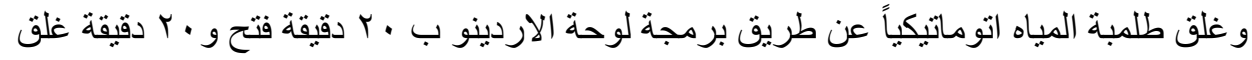

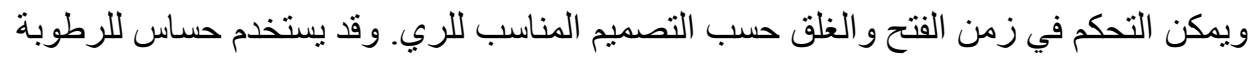

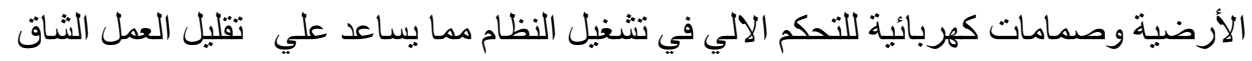
المستخدم في الري النبضي وتوفير الوقت و التكاليف. وحقق نظام التحكم الاتوماتيكي في الري

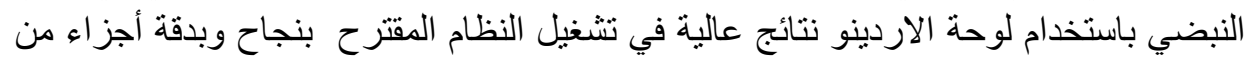

مدرس الهندسة الزراعيةـ قسم الهندسة الزراعية_ كلية الزراعةـ جامعة كفرالشيخ- مصر. 